\title{
FORMULASI SEDIAAN BLUSH ON EKSTRAK KAYU SECANG (CAESALPIINIA SAPPAN L) SEBAGAI PEWARNA ALAMI DALAM BENTUK POWDER
}

\author{
Sofyan Ramani ${ }^{1 *}$, Herson Cahaya Himawan², Nia Kurniawati ${ }^{3}$ \\ 1. Program Studi Farmasi Sekolah Tinggi Teknologi Industri dan Farmasi Bogor \\ 2. Program Studi Farmasi Sekolah Tinggi Teknologi Industri dan Farmasi Bogor \\ 3. Mahasiswa Program Studi S1 Farmasi Sekolah Tinggi Teknologi Industri dan Farmasi Bogor \\ Korespondensi:hersonindonesia2011@gmail.com
}

\begin{abstract}
ABSTRAK
Blush on adalah sediaan kosmetik yang digunakan untuk mewarnai pipi dengan sentuhan artistik sehingga dapat meningkatkan estetika dalam tatarias wajah dengan warna yang bervariasi mulai dari warna merah jambu hingga merah tua. Salah satu contoh yang dapat dijadikan pewarna alami adalah kayu secang (Caesalpinia sappan L) karena mengandung pigmen brazilein yang berfungsi sebagai pigmen warna. Tujuan penelitian ini membuat sediaan blush on dengan metode freeze drying dan konsentrasi warna alami. Pada penelitian ini dibuat 3 formula sediaan blush on dengan variasi konsentrasi 3\%, 5\%, dan 7\% ekstrak kering kayu secang. Dilakukan evaluasi sediaan blush on yang meliputi pengujian stabilitas fisika-kimia, organoleptis, homogenitas, daya oles, dan hedonik. Hasil pengujian stabilitas fisika-kimia menunjukkan blush on stabil dalam masa penyimpanan 7 hari. Hasil pengujian organoleptis, homogenitas, daya oles, menujukkan seluruh formula baik. Hasil pengujian hedonik menunjukkan bahwa serbuk blush on dengan ekstrak kayu secang konsentrasi $5 \%$ paling digemari.
\end{abstract}

\section{Kata kunci : Blush On pigmen, Evaluasi sediaan, Ekstrak Kayu secang}

\begin{abstract}
Blush is a cosmetic preparation used to color the cheeks with an artistic touch so as to enhance the aesthetics of facial makeup with a variety of colors ranging from pink to dark red. One example that can be used as a natural dye is sappan wood (Caesalpinia sappan L) because it contains brazilein pigment which functions as a color pigment. The purpose of this study is to make blush preparations with freeze drying method and natural color concentration. In this study, 3 blush-on formulations were made with variations in the concentration of $3 \%, 5 \%$, and $7 \%$ dry extract of secang wood. Blush on preparations were conducted which included physical-chemical stability, organoleptic, homogeneity, topical, and hedonic stability testing. Physical-chemical stability test results showed a stable blush on storage period of 7 days. Organoleptic test results, homogeneity, topical strength, showed all good formulas. The hedonic test results show that blush powder with secang wood extract concentration of $5 \%$ is most preferred.
\end{abstract}

Keywords: Blush pigment, Evaluation of preparations, Secang Wood Extract 


\section{PENDAHULUAN}

Kosmetik ialah sediaan atau bahan yang diperuntukkan pada bagian luar manusia (epidermis, bibir, kuku, rambut dan organ 1 bagian luar genetikal atau mulut mukosa dan gigi, terutama untuk membersihkan, memberikan parfum, memperbaiki bau badan mengubah penampilan, melindungi, dan/atau memelihara dalam kondisi baik [1]. Setiap wanita memiliki kecenderungan ingin tampak mmmpesona cantik dan menyenangkan untuk dipandang sehingga produk kosmetik menjadi keperluan utama bagi dirinya [2].

Blush on merupakan salah satu jenis tata rias yang mengaplikasikan warna pada pipi [3]. Blush on konvensional umumnya mengandung pigmen bewarna merah atau pigmen bewarna merah kecoklatan dengan kandungan yang tinggi. Blush on yang mengandung pigmen kadar rendah dipakai untuk pelembut warna [4]. Kandungan bahan pewarna sintetis dalam produk-produk kosmetik sangat berbahaya bagi kesehatan kulit. Bahaya yang ditimbulkan beragam seperti jerawat, flek hitam, dan iritasi. Salah satu pewarna sintetis yang dilarang digunakan sebagai bahan tambahan kosmetik menurut peraturan Kepala Badan Pengawas Obat Dan Makanan Republik Indonesia Nomor HK.03.1.23.08.11.07517 Tahun 2011 Tentang Persyaratan Teknis Bahan Kosmetika adalah Rhodamin B.

Pemakaian pewarna yang berdasar bahan alam dalam formulasi blush on merupakan salah satu cara untuk mengurangi pemakaian pewarna berbahan baku sintetik yang berbahaya. Diantara pewarna berbasis bahan alam yang memiliki potensi untuk dikembangkan antara lain berasal dari kayu secang (Caesalpinia sappan L) dengan warna merah sampai merah keunguan karena mengandung pigmen brazilein [5]. Brazilein merupakan pigmen berwarna merah yang bersifat mudah larut dalam air panas [6], sehingga proses ekstraksi dapat dilakukan dengan cara infundasi. Oleh karena itu peneliti ingin membuat sediaan blush on yang mengandung zat warna dari ekstrak kayu secang dengan metode freeze drying dalam bentuk powder.

\section{METODE PENELITIAN}

Bahan: Kayu secang telah diserut yang diperoleh dari Balitro, talkum, zink oksida, isopropil miristat, kaolin, mika (Magnesium Aluminium Silikat), dimetikon, nipagin dan oleum guava, akuades.

Alat: Alat gelas, neraca analitik (ACIS), blender (Sayota), lumpang dan alu, spatel, pengayak no.100 mesh, pH meter (ATC) yang sebelumnya dikalibrasi terlebih dahulu, cawan porselin, desikator, oven (Elos), freeze drying (Eyela).

\section{Metode}

\section{Pembuatan Serbuk Simplisia Kayu Secang}

Proses pembuatan serbuk simplisia diawali dengan cara $1 \mathrm{~kg}$ serutan kayu secang yang diperoleh dari Balitro dipotong hingga menjadi bagian yang kecil-kecil, setelah itu diblender sampai halus dan saring hingga didapat simplisia kayu secang dalam bentuk serbuk.

\section{Kadar air}

Metode thermogravimeti digunakan untuk menentukan kadar air yaitu dihitung dengan penentuan nilai susut pengeringan dengan metode cawan berbahan porselin dikeringkan pada temperature $105^{\circ} \mathrm{C}$ dalam waktu 30 menit, selanjutnya didinginkan di desikator kemudian bobotnya ditimbang. Dua gram simplisia diletakkan ke Cawan porselin tersebut selanjutnya dipanaskan dalam oven pada temperatur $105^{\circ} \mathrm{C}$ dalam waktu lebih kurang 13 jam. Cawan porselin yang berisi sampel diangkat dan didinginkan dalam desikator dan ditimbang bobotnya, dilakukan berulang sampai diperoleh bobot konstan [7]. Penetapan persentase kadar air dilakukan berdasarkan penentuan jumlah bobot kering simplisia dengan menggunakan rumus perhitungan kadar air, sebagai berikut:

$$
\text { Kadar air }(\%)=\frac{\text { Berat awal }- \text { Berat akhir }}{\text { Berat awal }} \times 100 \%
$$

Keterangan:

Bobot awal = bobot cawan+sampel sebelum dikeringkan - bobot cawan kosong(gram)
Bobot akhir $=$ bobot cawan + sampel sesudah dikeringkan - bobot cawan kosong (gram). 


\section{Pembuatan Ekstrak Air Kayu Secang}

Simplisia sebanyak 75 gram yang telah dihaluskan dicampur dengan $3000 \mathrm{ml}$ air ke panci, selanjutnya dipanaskan dalam waktu 15 menit di atas penangas air terhitung mulai suhu mencapai $90^{\circ} \mathrm{C}$ sambil sekali-sekali diaduk.
Serkai atau saring selagi panas melalui kain flannel [8]. Hasil filtrat yang diperoleh di freeze drying menggunakan alat freeze drying dengan suhu $40^{\circ} \mathrm{C}$ dan dihitung persen rendemen dengan rumus (Risnawati, 2012).

$$
\% \text { Rendemen }=\frac{\text { berat ekstrak yang didapat }(g)}{\text { berat simplisia awal }(g)} \times 100
$$

\section{Formulasi Sediaan Blush On}

Pada formulasi blush on di buat menjadi 3 formula dengan perbedaan konsentrasi zat warna kayu secang [11].

Tabel 2. Rancangan Formulasi Blush On dalam konsentrasi \% b/v

\begin{tabular}{|c|c|c|c|c|c|c|}
\hline No & $\begin{array}{l}\text { Nama } \\
\text { Bahan }\end{array}$ & Fungsi & $\begin{array}{c}\text { Formula } \\
\text { Basis } \\
(\%)\end{array}$ & $\begin{array}{c}\text { Formulasi } \\
\text { I } \\
(\%)\end{array}$ & $\begin{array}{c}\text { Formula } \\
\text { II } \\
(\%)\end{array}$ & $\begin{array}{c}\text { Formula } \\
\text { III } \\
(\%)\end{array}$ \\
\hline 1. & $\begin{array}{l}\text { Ekstrak } \\
\text { kering Kayu } \\
\text { Secang }\end{array}$ & Pewarna & - & 3 & 5 & 7 \\
\hline 2. & Zink Oxide & Pelekat & 0,7 & 0,7 & 0,7 & 0,7 \\
\hline 3. & Kaolin & Pelekat & 1 & 1 & 1 & 1 \\
\hline 4. & $\begin{array}{l}\text { Isoprophyl } \\
\text { Miristat }\end{array}$ & Pengikat & 0,75 & 0,75 & 0,75 & 0,75 \\
\hline 5. & Mika & Zat Penstabil & 20 & 20 & 20 & 20 \\
\hline 6. & Dimetikon & Pelembut & 10 & 10 & 10 & 10 \\
\hline 7. & Nipagin & Pengawet & 0,18 & 0,18 & 0,18 & 0,18 \\
\hline 8. & Talk & Basis & Ad 10 & Ad 10 & Ad 10 & Ad 10 \\
\hline 9. & $\begin{array}{l}\text { Oleum } \\
\text { Guava }\end{array}$ & Parfum & q.s & q.s & q.s & q.s \\
\hline
\end{tabular}

\section{Pembuatan Sediaan Blush On}

Zink oxide digerus dan diayak terlebih dahulu dengan pengayakan no. 100 mesh, kemudian dimasukkan kaolin dan zink oxide sebagai emollient, mika atau veguum sebagai stabilizing agent, dan metilparaben sebagai pengawet dalam sediaan ke dalam blender, masukkan zat warna ekstrak kering kayu secang sebagai pengganti warna sintetik hingga warna tercampur rata, kemudian tambahkan sedikit atau sebagian talkum sebagai basis utama dalam pembuatan blush on.

Isopropil miristat yang telah dipanaskan terlebih dahulu dimasukkan kedalam blender hingga tercampur, kemudian ditambahkan dimetikon sebagai pelembut dan masukkan sisa talkum blender hingga tercampur, tambahkan minyak jambu sebagai parfum hingga tercampur rata, kemudian ayak dengan pengayakan no. 100 tujuannya untuk melihat

homogenitas. Penyimpanan sediaan di wadah tertutup yang kedap udara dan terhindar dari paparan sinar matahari agar zat aktif tidak teroksidasi.

\section{Evaluasi Sediaan Blush On}

Uji mutu sediaan yang meliputi:

1. Uji Organoleptik

Uji organoleptik terdiri dari bau, warna dan penetapan bentuk, dapat dideteksi oleh panca indera. Penetapan 
4 Sofyan Ramani et al., (Formulasi Sediaan Blush On Ekstrak Kayu Secang ...)

organoleptik dilakukan sebagai spesifikasi produk.

warna yang melekat pada punggung kulit tangan merah dan jumlahnya banyak [10].

2. Uji Homogenitas

Uji Homogenitas memakai object glass. Pada sekeping kaca sejumlah tertentu sediaan dioleskan, sediaan harus menunjukkan tidak adanya butiran kasar dan memeiliki susunan yang homogen [9].

3. Uji pH (derajad keasaman )

$\mathrm{pH}$ universal digunakan untuk pengukuran derajad keasaman. Pengukuran derajad keasaman dilakukan dengan cara memasukkan $\mathrm{pH}$ universal ke dalam sediaan blush on, sejumlah 1 gram sediaan dilarutkan dalam air dengan volume $10 \mathrm{~mL}$, kemudian diukur derajad keasamannya-nya menggunakan $\mathrm{pH}$-universal. Syarat $\mathrm{pH}$ sediaan perona pipi yang baik sesuai dengan $\mathrm{pH}$ kulit secara umum adalah 4 -7 [4].

4. Uji Daya Oles

Uji daya oles dilakukan secara visual oleh 10 orang panelis dengan cara mengoleskan blush on pada punggung kulit tangan selanjutnya mengamati kuantitas warna yang dapat melekat dengan kuantitas perlakuan sebanyak 5 kali pengolesan. Sediaan blush on dikategorikan baik dan memiliki daya oles yang baik apabila

5. Uji Kesukaan (Hedonik)

Uji kesukaan dilaksanakan untuk memahami tingkat kesukaan panelis. Panelis diminta untuk mencoba 3 formulasi blush on yang berbeda, kemudian panelis diminta untuk memberikan tanggapan dan penilaian atas ketiga formulasi blush on yang telah dicoba. Uji kesukaan dilakukan terhadap 10 orang panelis wanita dengan rentang usia 20-27 tahun, dengan cara pengisian kuisioner. Parameter pengujian meliputi tekstur, warna, dan aroma atau bau, dengan kriteria penilaian:

1. Sangat Suka

2. Suka

3. Cukup Suka

4. Tidak suka

5. Sangat tidak Suka

\section{Analisis Data}

Data hasil pengujian uji hedonik blush on akan dianalisis dengan program SPSS 17 yang menggunakan uji analisis statistik Friedman.

\section{HASIL DAN PEMBAHASAN}

\section{Hasil Serbuk Simplisia Kayu Secang}

Serbuk kayu secang yang dihasilkan berwarna orange kecoklatan, berbau khas kayu.

Gambar 3. Serbuk Kayu Secang (Caesalpinia sappan L) 
5 Sofyan Ramani et al., (Formulasi Sediaan Blush On Ekstrak Kayu Secang ...)

\section{Hasil Kadar Air}

Berdasarkan perhitungan hasil diperoleh kadar air sebesar 4,5\%.

\section{Hasil Ekstraksi Air Kayu Secang}

Ekstraksi kayu secang dilakukan dengan metode cara panas yaitu infusa. Metode infusa ialah ekstraksi menggunakan pelarut air pada temperature $90^{\circ} \mathrm{C}$ selama 15 menit di penangas air (Ditjen POM, 2000).
Dalam penelitian ini pelarut yang digunakan yaitu air, dan didapat ekstrak air sebanyak $2500 \mathrm{ml}$ berwarna merah dengan nilai $\mathrm{pH}$ 7,4. Ekstrak zat warna kayu secang dipengaruhi oleh cara isolasi jenis pelarut, volume ekstraktor, dan ukuran sampel (Padmaningrum, 2012). Setelah proses ekstraksi, filtrat sebanyak 2000 ml dilakukan freeze drying dan didapatkan ekstrak kering dengan persentase rendemen ekstrak sebesar $0,5 \%$.

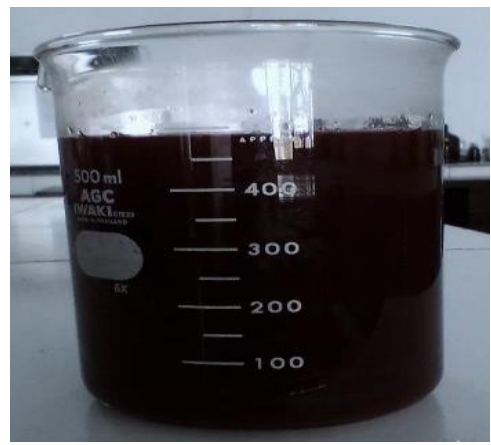

\section{Gambar 4. Ekstrak Air Kayu Secang (Caesalpinia sappan L)}

\section{Hasil Pembuatan Sediaan Blush On}

Formulasi blush on dengan konsentrasi ekstrak kayu secang yaitu 3\%, 5\%, dan $7 \%$ sehingga menghasilkan perbedaan intensitas warna blush on. Penambahan konsentrasi ekstrak sediaan dengan menyebabkan warna menjadi semakin pekat, seperti terlihat dilihat pada Gambar 5.

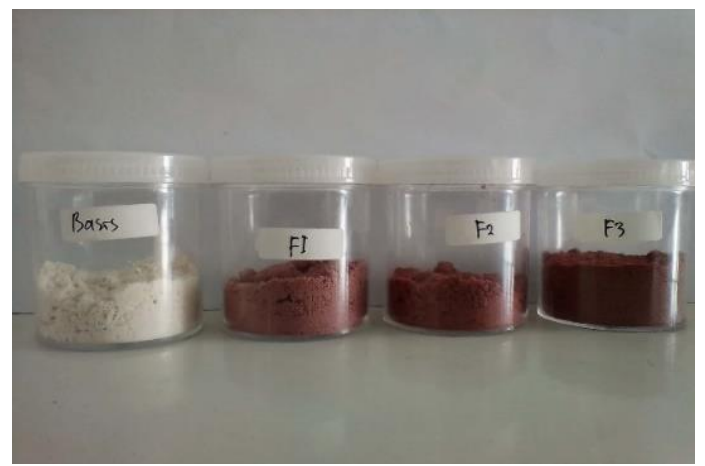

Gambar 5. Sediaan Blush On

Keterangan :

Basis : Blush on tanpa ekstrak (Plasebo)

F1 : Blush on dengan konsentrasi zat warna $3 \%$

F2 : Blush on dengan konsentrasi zat warna $5 \%$
F3 : Blush on dengan konsentrasi zat warna $7 \%$

\section{Evaluasi Sediaan Blush On}

Evaluasi sediaan blush on dari ekstrak kayu secang dilakukan dengan cara sebelum dan sesudah stabilitas dengan masa 
penyimpanan selama 7 hari pada suhu kamar. Pengujian meliputi pemeriksaan organoleptik, homogenitas, $\mathrm{pH}$. Uji daya oles, Uji kesukaan (Hedonik).

\section{Hasil Uji Organoleptik}

Berdasarkan tabel di bawah ini, secara organoleptik pada hari ke- 0 , keempat formula blush on berbentuk powder. Pada formula basis tidak berbau dan warna putih. Pada formula 1 ,
2, dan 3 memiliki bau oleum guava dan warna ungu muda - ungu pekat. Warna ungu pada formula 1, 2 dan 3 disebabkan karena zat warna ekstrak kayu secang yang dihasilkan berwarna merah maroon sehingga pada saat dicampur dengan basis berwarna putih menghasilkan warna ungu. Selain itu bau guava pada formula 1, 2, dan 3 disebabkan karena penambahan oleum guava.

Tabel 3. Data Hasil Organoleptik

\begin{tabular}{|c|c|c|c|}
\hline \multirow[b]{2}{*}{ Formula } & \multirow[b]{2}{*}{ Kriteria } & \multicolumn{2}{|c|}{ Pengamatan } \\
\hline & & Hari Ke-0 & Hari ke-7 \\
\hline Basis & $\begin{array}{l}\text { Warna } \\
\text { Aroma } \\
\text { Bentuk }\end{array}$ & $\begin{array}{l}\text { Putih } \\
\text { Tidak Berbau } \\
\text { Powder }\end{array}$ & $\begin{array}{l}\text { Putih } \\
\text { Tidak Berbau } \\
\text { Powder }\end{array}$ \\
\hline $\mathrm{F} 1$ & $\begin{array}{l}\text { Warna } \\
\text { Aroma } \\
\text { Bentuk }\end{array}$ & $\begin{array}{l}\text { Ungu Muda } \\
\text { Oleum } \\
\text { Guava } \\
\text { Powder }\end{array}$ & $\begin{array}{l}\text { Ungu Muda } \\
\text { Oleum Guava } \\
\text { Powder }\end{array}$ \\
\hline $\mathrm{F} 2$ & $\begin{array}{l}\text { Warna } \\
\text { Aroma } \\
\text { Bentuk }\end{array}$ & $\begin{array}{l}\text { Ungu } \\
\text { Oleum Guava } \\
\text { Powder }\end{array}$ & $\begin{array}{l}\text { Ungu } \\
\text { Oleum Guava } \\
\text { Powder }\end{array}$ \\
\hline F3 & $\begin{array}{l}\text { Warna } \\
\text { Aroma } \\
\text { Bentuk }\end{array}$ & $\begin{array}{l}\text { Ungu Tua } \\
\text { Oleum Guava } \\
\text { Powder }\end{array}$ & $\begin{array}{l}\text { Ungu Tua } \\
\text { Oleu Guava } \\
\text { Powder }\end{array}$ \\
\hline
\end{tabular}

*Stabilitas dilakukan selama 7 hari pada suhu kamar

Keterangan :

Basis : Blush on tanpa ekstrak (plasebo)

F1 : Blush on dengan konsentrasi zat warna $3 \%$

F2 : Blush on dengan konsentrasi zat warna $5 \%$

F3 : Blush on dengan konsentrasi zat warna $7 \%$

Hasil uji stabilitas pada hari ke-7 secara organoleptik yang tidak mengandung ekstrak tetap tidak berbau, bewarna putih dan berbentuk powder. Pada formula yang mengandung zat warna ekstrak kayu secang masih terlihat bewarna ungu dan pada aroma tidak terjadi perubahan pada sediaan blush on, bentuk dari keempat sediaan masih tetap powder, sehingga dapat disimpulkan dari keempat formula tersebut tidak menunjukan adanya perubahan warna, aroma, dan bentuk selama 7 hari penyimpanan sediaan blush on masih stabil. Hal ini dikarenakan selama masa penyimpanan sediaan blush on tersimpan dalam wadah yang tertutup dengan rapat dan tidak terpapar dari cahaya.

\section{Hasil Pengujian Homogenitas}

Pemeriksaan homogenitas dilakukan untuk mengobservasi adanya partikel-partikel yang bersifat kasar pada sediaan menggunakan kaca objek dan homogenitas penyebaran warna pada 
punggung tangan, syarat homogenitas adalah tidak boleh mengandung bahan kasar yang bisa di raba [11]. Hasil pengujian homogenitas pada semua sediaan blush on menunjukan hasil yang homogen terlihat dari kaca objek. Hasil pengujian homogenitas dapat dilihat pada Tabel 4.

Tabel 4. Data Hasil Homogenitas

\begin{tabular}{ccc}
\hline \multirow{2}{*}{ Formulasi } & Hari Ke-0 & Hari Ke-7 \\
\hline Basis & Homogen & Homogen \\
F1 & Homogen & Homogen \\
F2 & Homogen & Homogen \\
F3 & Homogen & Homogen \\
\hline
\end{tabular}

*Stabilitas dilakukan selama 7 hari pada suhu kamar

Keterangan :

Basis : Blush on tanpa ekstrak (plasebo)

F1 : Blush on dengan konsentrasi zat warna $3 \%$

F2 : Blush on dengan konsentrasi zat warna $5 \%$

F3 : Blush on dengan konsentrasi zat warna $7 \%$

Hasil uji stabilitas pada hari ke-7 secara homogenitas menunjukkan bahwa sediaan blush on ekstrak buah naga merah tetap homogen selama waktu penyimpanan, karena tidak terlihat adanya butiran-butiran kasar dan terlihat transparan pada kaca dan permukaannya halus merata.

\section{Hasil Pengujiaan pH}

Sediaan blush on diuji $\mathrm{pH}$ untuk mengetahui apakah sediaan berada pada rentan $\mathrm{pH}$ normal kulit, yaitu 4-7 [4]. Pengujian menggunakan $\mathrm{pH}$ universal dengan cara mencelupkan $\mathrm{pH}$ universal ke dalam sediaan blush on.

Berdasarkan pengujian $\mathrm{pH}$ yang dilakukan terhadap sediaan blush on tanpa penambahan ekstrak kayu secang memiliki nilai $\mathrm{pH}$ yang lebih besar yaitu sebesar 7 karena tidak adanya penambahan asam dan perubahan warna. Sedangkan sediaan blush on dengan penambahan zat warna ekstrak kayu secang pada formula 1, 2, dan 3 memiliki nilai derajad keasaman yang sama yaitu 6. Hasil pengujian $\mathrm{pH}$ dapat dilihat pada Tabel 5 .

Tabel 5. Data Hasil Pengujian pH

\begin{tabular}{|c|c|c|c|c|c|}
\hline \multirow[b]{2}{*}{ No } & \multirow[b]{2}{*}{ Waktu } & \multicolumn{4}{|c|}{ Rata-rata pH } \\
\hline & & Basis & Formula 1 & Formula 2 & Formula 3 \\
\hline 1. & Hari ke-0 & 7 & 6 & 6 & 6 \\
\hline 2. & Hari ke-7 & 7 & 7 & 6 & 7 \\
\hline
\end{tabular}

Berdasarkan hasil pengamatan pada hari ke-0 $\mathrm{pH}$ untuk basis memilki sifat netral sedangkan untuk formula 1, 2 dan 3 memilik pH 6 tidak berbeda jauh dengan basis begitu pada hari ke ke 7 menunjukkan nilai $\mathrm{pH}$ yang cenderung tidak ada perbedaan berarti dan cenderung sama yakni pH 7. Hasil uji stabilitas pada hari ke-7 nilai $\mathrm{pH}$ pada formula 1 dan 3 mengalami peningkatan yaitu sebesar 7. Peningkatan nilai $\mathrm{pH}$ disebabkan pada saat penyimpanan kemungkinan terjadi pada tutup wadah yang tidak rapat sehingga mempengaruhi $\mathrm{pH}$.
Selain itu pH 7 baik itu basis maupun formula 1, 2 dan 3 bahan $\mathrm{pH}$ disebabkan oksidasi dengan adanya oksigen dari atmosfer [12]. Peningkatan nilai $\mathrm{pH}$ keempat formula tidak terlalu signifikan dan masih sesuai dengan $\mathrm{pH}$ kulit yaitu 4-7 (Wasitaatmadja, 1997), sehingga sediaan yang dihasilkan stabil dalam penyimpanan selama 7 hari.

\section{Hasil Pengujian Daya Oles}

Hasil pengujian daya oles pada hari ke-0 menunjukkan bahwa seluruh formula sediaan 
blush on menghasilkan pengolesan yang sangat baik setelah 5 kali pengolesan. Sediaan blush on dengan konsentrasi 3\% menghasilkan warna ungu pucat. Sediaan blush on dengan konsentrasi 5\% menghasilkan warna ungu dan sediaan blush on dengan konsentrasi $7 \%$ menghasilkan warna ungu muda.

Berdasarkan hasil pengujian daya oles pada hari ke-7 menunjukkan bahwa seluruh formula sediaan blush on sangat baik setelah 5 kali pengolesan dan tidak terjadi perubahan warna selama penyimpanan.

\section{Hasil Pengujian Kesukaan (Hedonik)}

Uji kesukaan ini dilakukan untuk mengetahui tingkat kesukaan panelis terhadap sediaan blush on dari ekstrak kayu secang (Caesalpinia sappan $\mathrm{L}$ ).

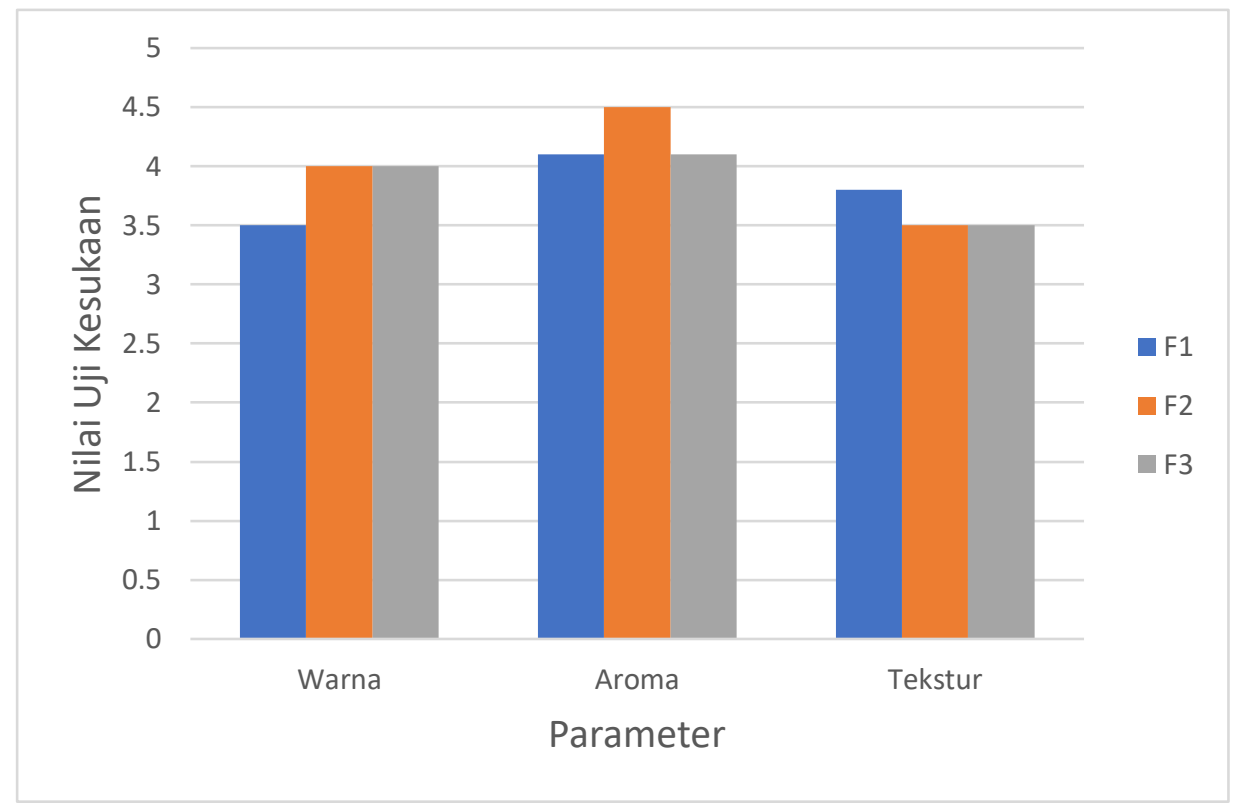

Gambar 6. Diagram Uji Hedonik

Keterangan :

Basis : Blush on tanpa ekstrak (plasebo)

F1 : Blush on dengan konsentrasi zat warna $3 \%$

F2 : Blush on dengan konsentrasi zat warna $5 \%$

F3 : Blush on dengan konsentrasi zat warna $7 \%$

Berdasarkan hasil uji kesukaan pada gambar 6. Sediaan yang disukai untuk parameter warna adalah formula 2 dan 3 . Hasil penilaian warna dilihat berdasarkan adanya warna ungu saat dilakukan pengolesan pada punggung tangan, terpilihnya formula 2 dan 3 pada parameter warna dikarenakan warna yang dihasilkan pada formula 2 dan 3 lebih terlihat warnanya dibandingkan formula 1 . Hal tersebut terjadi karena zat warna ekstrak kayu secang pada formula 2 dan 3 lebih banyak konsentrasinya dibandingkan formula 1 , semakin tinggi konsentrasi maka semakin pekat warna sediaan [11]. Pada parameter aroma, dilihat dari adanya aroma jambu dalam sediaan, hasil yang diperoleh adalah pada formula 2 artinya lebih suka dibandingkan dengan formula 1 dan 3.

Pada tekstur diamati berdasarkan tingkat kelembutan dan kelengketan sediaan, sediaan yang banyak disukai untuk parameter tekstur adalah sediaan formula 1 , hal tersebut dikarenakan formula 1 lebih sedikit zat warnanya sehingga lebih lembut dan tidak lengket pada saat pengolesan. Berdasarkan hasil skor uji kesukaan yang telah diujikan kepada 10 panelis wanita, hasil yang diperoleh yaitu sebanyak $34 \%$ panelis menyukai formula 2 yaitu sediaan yang mengandung zat warna ekstrak kayu secang 5\%. Hal ini dikarenakan pada formula 2 warna lebih natural sehingga tidak pucat dan mencolok.

\section{Hasil Analisis Data}

Hasil pengujian hedonik sediaan blush on akan dianalisis dengan program SPSS 17 yang menggunakan uji analisis statistik Friedman, 
yaitu untuk mengetahui ada tidaknya perbedaan antara warna, aroma dan tekstur pada formula 1, 2 dan 3 sediaan blush on.

Dari hasil analisis diperoleh nilai signifikasi pada warna, aroma dan tekstur $>0,05$

\section{SIMPULAN}

1. Ekstrak kayu secang sebagai pewarna alami dapat diformulasikan menjadi sediaan blush on dengan kosentrasi ekstrak kering sebesar $3 \%, 5 \%$ dan $7 \%$ dengan uji mutu sediaan yang baik.

2. Berdasarkan hasil skor akhir pada uji kesukaan (hedonik) konsentrasi yang lebih disukai adalah konsentrasi $5 \%$.

3. Berdasarkan hasil analisis data uji hedonik bahwa tidak ada perbedaan nyata antara warna, aroma dan tekstur.

\section{SARAN}

1. Perlu dilakukan uji stabilitas yang lebih lama dari sediaan blush on.

2. Perlu dilakukan penelitian mengenai uji aktivitas ekstrak kayu secang, antioksidan dan uji iritasi.

\section{DAFTAR PUSTAKA}

[1] Tranggono, R.I. Latifah, F. 2007. Buku Pegangan Ilmu Pengetahuan Kosmetik. Jakarta: Penerbit PT Gramedia Pustaka Utama. Hlm: 90-96

[2] Farima, Devi. 2009. Karakteristik dan Ekstraksi Simplisia Tumbuhan Bunga Mawar (Rosa hybrida L) Serta Formulasinya dalam Sediaan Pewarna Bibir. [Skripsi]. Medan : Universitas Sumatera Utara.

[3] Wasitaatmadja, S.M. 1997. Penuntun ilmu kosmetik medik. Jakarta: UI-press. sehingga hipotesis $\mathrm{H}_{0}$ diterima. Hasil tersebut memberikan kesimpulan bahwa tidak ada perbedaan secara bermakna antara warna, aroma dan tekstur.

[4] [DITJEN POM] Direktorat Jendral Pengawasan Obat dan Makanan. 1985. Formularium Kosmetik Indonesia. Jakarta: Departemen Kesehatan RI

[5] Indriani, H. 2003. Stabilitas Pigmen Alami Kayu Secang (Caesalpinia sappan $L$ )dalam Model Minuman Ringan [Skripsi]. Insitut Pertanian. Bogor.

[6] Puspaningrum, R. 2003. Pengaruh Bubuk Pewarna Makanan Alami Kayu Secang (Caesalpinia sappan L) Dengan Metode Spray Drying. [Skripsi]. Bogor : IPB

[7] [AOAC] Association of Analytical Chemist. 2005. Official Methods of Analysis. Washington DC :AOAC Publisher.

[8] BPOM. 2011. Caesalpinia sappan Lim. Jakarta: Direktorat Obat Asli Indonesia. Hlm 85.

[9] Departemen Kesehatan Republik Indonesia. 1995. Farmakope Indonesia Edisi IV. Jakarta : Departemen Kesehatan RI

[10] Keithler. 1956. Formulation of Cosmetic and Cosmetic Specialities. New York : Drug and Cosmetic Industry

[11] Syamsuni H.A., 2006. Ilmu Resep. Jakarta : EGC

[12] Martin, A., Cammarta, dan Swarbrick. 1993. Farmasi Fisik. Edisi III Jilid 2. Jakarta: Universitas Indonesia 